\title{
Virtual Water, Water Scarcity, and International Trade Law
}

Edith Brown Weiss

Georgetown University Law Center, weiss@law.georgetown.edu

Lydia Slobodian

International Union for Conservation of Nature Environmental Law Centre, lydia.slobodian@iucn.org

This paper can be downloaded free of charge from:

https://scholarship.law.georgetown.edu/facpub/1623

http://ssrn.com/abstract=2734369

17 J. Intl. Econ. Law 717-737 (2014)

This open-access article is brought to you by the Georgetown Law Library. Posted with permission of the author. Follow this and additional works at: https://scholarship.law.georgetown.edu/facpub

Part of the Environmental Law Commons, and the International Trade Law Commons 


\title{
Virtual Water, Water Scarcity, and International Trade Law
}

\author{
Edith Brown Weiss ${ }^{*+}$ and Lydia Slobodian**
}

\section{INTRODUCTION}

We are facing a fresh water crisis during this century. In less than two decades, by 2030 , the requirements for fresh water are expected to exceed the currently available and accessible fresh water supplies by $40 \% .{ }^{1}$ Many countries are expected to be water stressed later in this century; some areas of the world already are. Some people may even lack water to meet basic human needs, such as drinking, washing, and sanitation. In rural areas in certain regions, people may lack water to grow good food crops, even for their own consumption. This has major implications for the welfare of the world's population and for the integrity and violability of ecosystems.

At a minimum, we are facing a series of local or regionalized fresh water crises, which will have global political, economic, and social repercussions. More likely, these localized and regional water crises will also lead to a global fresh water crisis in the sense that sufficient water will not be available for the purposes needed and at the time needed. Fossil ground water aquifers will be increasingly depleted, and technology may not be sufficient to ensure secure water supplies. While the details of the pending fresh water crisis have been set forth elsewhere, the implications for the trade in virtual water and the application of international trade law need to be further addressed. $^{2}$ This article focuses on this connection.

Fresh water is essential to our lives and to our planet. There is no known substitute. Only about $2.5 \%$ of Earth's water is fresh water, and of this, only $0.4 \%$ is surface water, and about $30 \%$ is ground water. ${ }^{3}$ Most of the rest is in glaciers and icecaps,

* Francis Cabell Brown Professor, International Law, Georgetown University Law Center. Email: weiss@law.georgetown.edu

** Legal Officer, International Union for Conservation of Nature Environmental Law Centre. Email: lydia.slobodian@iucn.org

+ This article is dedicated to my valued colleague and friend, John H. Jackson, with great appreciation for our stimulating collaboration on environment and trade issues.

12030 Water Resources Group, Charting Our Water Future, 5 (2009). New York: McKinsey Co., International Finance Corporation.

2 See Edith Brown Weiss, International Law for a Water-Scarce World (The Hague: Martinus Nijhoff, 2013), briefly treating virtual water and international trade law.

3 United Nations Environment Programme (UNEP), Global Environment Outlook 4 (Nairobi: UNEP, 2007) 118.

(C) The Author 2014. Published by Oxford University Press. All rights reserved. 
which are mostly inaccessible. About $70 \%$ of water used today is for agriculture, and more than $90 \%$ of water consumed is for agriculture. ${ }^{4}$ This means that agriculture provides the global framework within which the trade in virtual water and international trade law must be considered. Water quality is also important, since pollution reduces the amount of water available for human use. Agriculture is one of the major polluters of both ground and surface water. At the same time, water for agriculture may suffer from pollution caused by other sources.

The central economic feature of fresh water is that generally it does not have a price attached to it. The only costs are for extraction and delivery of supplies, and these may be subsidized. Thus, while we face a crisis in the availability of fresh water, with agriculture as the biggest user, there are few, if any, economic incentives to conserve water or to use it efficiently.

Understandably, there is great concern about the commodification of water. Resolutions adopted by the United Nations General Assembly and the Human Rights Council in 2010 posit a human right to water and to sanitation. ${ }^{5}$ While there is no formal consensus specifying the contents of such a right to water, it is generally considered to cover the amount of water necessary for drinking and bathing, and for sanitation. Many would argue that it also covers the amount of water necessary for subsistence agriculture to feed oneself and family in rural areas, and in this sense links with a right to food. Because of concerns about sufficient water to meet basic needs and for various cultural reasons, many people have been reluctant to accept any commodification of fresh water. But the result is that large agribusiness, in particular, gains from a free resource, while poor people often suffer.

There is not only a crisis in the availability of fresh water supplies but also in their geographic distribution. Supplies are unequally distributed in the world. Regions with arid climates and with limited water resources are estimated to cover large parts of Africa (northern and southern Africa), 60\% of Asia, 33\% of Europe, 30\% of Latin America, the southwestern part of North America, and most of Australia. ${ }^{6}$ Most of the Middle East is arid with limited water resources. Within countries, the areas that are water rich may not match those in which there is the greatest demand for water. Thus, as we address issues of virtual water and international trade, we have to consider both the physical supply and the equity issues.

The proposed post-2015 Sustainable Development Goals recognize the importance of managing agricultural trade to promoting food security and sustainable development, including through eliminating agricultural subsidies (goal 2.b). The Goals also include objectives to increase substantially water use efficiency across all

4 United States Intelligence Community, Intelligence Community Assessment: Global Water Security (Washington, D.C.: National Intelligence Council, 2012) ii (referencing World Bank data).

5 The human right to water and sanitation, United Nations General Assembly resolution 64/292, A/RES/ 64/292, adopted 28 July 2010; Human Rights and access to safe drinking water and sanitation, United Nations Human Rights Council resolution 15/9, A/HRC/RES/15/9, adopted 30 September 2010.

6 Igor A. Shiklomanov, 'World Fresh Water Resources', in Peter Gleick (ed), Water in Crisis (Oxford: Oxford University Press, 1993) 16. See also H.L. Saeijs and M.J. Van Berkel, 'Global Water Crisis: The Major Issue of the $21^{\text {st }}$ Century', 5 European Water Pollution Control 26 (1995). Shiklomanov provides various tables on water distribution among countries and river basins. Later studies point to a worsening water crisis. 
sectors by 2030, while at the same time achieving universal access to safe and affordable drinking water and adequate sanitation (goals 6.1 and 6.4). ${ }^{7}$

Conceptually, the problem is how to get fresh water from where it is in excess to where it is needed and to encourage efficient water use. Normally, fresh water flows naturally across national borders in rivers or streams, or in some cases slowly in transboundary aquifers. Two major international conventions cover these natural transboundary water flows: the UN Convention on the Law of the Non-Navigational Uses of International Watercourses, which entered into force in August 2014, and the UNECE Convention on the Protection and Use of Transboundary Watercourses and International Lakes, which opened for accession by non-UNECE countries in February 2013. Both Conventions promote the principle of equitable and reasonable use of transboundary watercourses, and establish substantive and procedural obligations to guide countries in sustainably managing and sharing water resources. These instruments are critical to improving sustainable water use in shared basins and aquifers.

The question remains, though, of how to manage water transfers between regions or between countries that do not share a water resource, in order to reduce pressure on water scarce regions, and to increase efficiency of water use. With other goods such as oil, coal or natural gas, we can physically transport the resource. Fresh water is different. For the most part, we do not engage in artificial bulk transport of physical water across national boundaries, because of the difficult of doing so, the water loss rate, and the cost.

One approach to understanding and managing water transfers between regions is to view fresh water in terms of 'virtual water'. The concept was first articulated in the early to mid-1990s. ${ }^{8}$ Under this concept, the focus is not on the physical transfer of water but rather on the amount of water used to produce a given product. ${ }^{9}$ Not surprisingly, most of the trade in virtual water involves the agricultural sector, since agriculture accounts for more than $70 \%$ of fresh water use, and more than $90 \%$ of fresh water consumption. Countries with limited fresh water supplies can limit the burden on them by becoming net importers of goods that are water-intensive, while those countries with plentiful water resources can profit by becoming net exporters of water-intensive goods. Producers of water intensive products can relocate to areas where climate and other conditions are more conducive to efficient use of water. Water consumption will thus be reduced on the global scale. While reality is more complicated, the concept of international trade in virtual water reflects this premise.

International trade rules apply to this trade in virtual water. The rules and potential changes in the rules applicable to the agricultural sector may have unforeseen

7 Proposed Sustainable Development Goals, 19 July 2014, available at http://sustainabledevelopment.un. org/focussdgs.html.

8 John Anthony Allan, 'Fortunately There are Substitutes for Water: Otherwise Our Hydropolitical Futures Would be Impossible', in Priorities for Water Resources Allocation and Management (London: Overseas Development Administration, 1992) 13-26; John Anthony Allan, 'Virtual Water: A Strategic Resource, Global Solutions to Regional Deficits', 36 Groundwater 545-546 (1998).

9 Arjen Y. Hoekstra and Ashok K. Chapagain, Globalization of Water: Sharing the Planet's Freshwater Resources (Oxford: Blackwell Publishing, 2008) 8-10. The authors argue that 'use' can be quantified, as distinguished from the term 'water needed' to produce a product, which is subject to interpretation. 
implications for the trade in virtual water and most importantly for the fresh water crisis. Unless water has a price, trade liberalization in the agricultural sector may inadvertently intensify the fresh water-scarcity crisis. On the other hand, measures designed to encourage water efficiency and to give consumers information about water sources and water intensity will need to comply with international trade rules.

This article explores these issues and is intended to provide a preliminary analysis to generate further discussion and potentially lead to policy deliberations.

\section{A. Trade in virtual water}

Virtual water describes water that is used to produce a product, but is not necessarily contained in the final product. The term 'water footprint' describes all the virtual water contained in or used by a certain product, country, or individual. When a product is traded internationally, the virtual water it contains is transferred to the importing country, increasing that country's water footprint. At the turn of the 21 st century, an estimated 1625 billion cubic meters per year of virtual water flowed in international trade. ${ }^{10}$

Most virtual water is used in agricultural products and their derivatives. However, some of these agricultural products are then used as inputs into other products, such as clothing or processed food, so that ultimately agricultural products make up only an estimated $35 \%$ of the consumer-level water footprint; processed food makes up $22 \%$; industrial products make up $23 \%$; and services, including residential water utilities, make up $21 \%$. $^{11}$

Estimates differ as to what percentage of virtual water enters international trade. Allan, for example, estimates $15 \%$ of virtual water contained in agricultural crops and livestock enters international trade. ${ }^{12}$ Zhan-Ming and Chen estimate that one-third of global water withdrawal is used for products (or inputs into other products) that ultimately enter international trade. ${ }^{13}$ The estimates reflect differences in how virtual trade is modeled and in what is measured. But in all cases, the estimates indicate that virtual water is significant in international trade. Notably, the trade in virtual water is the greatest among a handful of mostly developed countries. ${ }^{14}$

\section{B. Virtual water and water scarcity}

Increasing trade in virtual water is often championed as a way to improve efficiency in the use of water globally and to distribute resources from water-rich to water-poor countries and thereby alleviate food insecurity that could result from

10 Ibid.

11 Chen Zhan-Ming and Guoquian Chen, 'Virtual Water Accounting for the Globalized World Economy: National Water Footprint And International Virtual Water Trade', 28 Ecological Indicators 142-149 (2013).

12 John Anthony Allan, 'Prioritising the Processes beyond the Water Sector that will Secure Water for Society - Farmers, Fair International Trade and Food Consumption And Waste', in Luis MartínezCortina, Alberto Garrido, and Elena López-Gunn (eds), Re-thinking Water and Food Security: Fourth Botín Foundation Water Workshop (London: Taylor \& Francis, 2010).

13 Zhan-Ming and Chen, above $\mathrm{n} 11$.

14 Megan Konar et al., 'Water For Food: The Global Virtual Water Trade Network', 47 Water Resources Research W05520 (2011). 
water scarcity. ${ }^{15}$ While the trade in virtual water can accomplish some of this, it is also important to note its limitations, as identified below.

International trade in water-intensive products can save water on the global level by shifting production of water-intensive products to areas where such production is more efficient because of low rates of evapotranspiration, favorable soil conditions, other environmental conditions, or technological factors. A study by Hoekstra and Chapagain estimates that international trade in agricultural products (including crops and livestock) results in a global saving of 350 billion cubic meters of water per year. ${ }^{16}$ The estimate is based on the difference between the water needed to grow crops in the country where they are grown and the water that would be needed to grow the same crops in the country where they are consumed, due to differences in climate and rates of evapotranspiration. This figure has been generally accepted in the virtual trade research community. ${ }^{17}$ The overall global water saving from trade has also been estimated as $6 \%$ of agricultural water use. ${ }^{18}$

In theory, trade in virtual water could also address problems related to the uneven distribution and use of water resources by facilitating transfer of virtual water from water-rich to water-poor countries. In practice, evidence for this has been mixed. Though researchers have found evidence that certain crops are traded from waterrich to water-poor countries, comprehensive global studies have found no connection between trade in virtual water and water scarcity. ${ }^{19}$

In a 2011 study of water use and water availability across the globe, Seekell, D'Odorico, and Pace found that while there are large differences between countries in the availability and abundance of water resources, there are relatively small differences between countries in water use. ${ }^{20}$ In other words, water-poor countries are currently using about the same amount of water as water-rich countries, which indicates that water-rich countries are not fully exploiting their water resources, whereas water-poor countries are using their resources unsustainably. The researchers found the least variation in the use of water for internal agricultural production, which was also the greatest use of water. The amount of water transferred through international trade was insignificant compared to the amount used for internal agricultural production. Existing disparities in distribution of water resources also eclipsed the amount of virtual water traded. They concluded that the amount of virtual water traded

15 Allan, above n 12; World Trade Organization, World Trade Report 2010: Trade in natural resources (Switzerland: World Trade Organization, 2010); Hoekstra and Chapagain, above n 9.

16 Hoekstra and Chapagain, above $\mathrm{n} 9$.

17 For example, World Trade Organization, above n 15; Alexandre Le Vernoy and Patrick Messerlin, 'Water and the WTO: Don't Kill the Messenger', Strategic Workshop on: 'Accounting for Water Scarcity and Pollution in the Rules of International Trade' (Amsterdam: Groupe d'Economie Mondiale - Sciences Po, 10 January 2011).

18 Ashok K. Chapagain, Arjen Y. Hoekstra, and Huub H.G. Savenije, 'Saving Water Through Global Trade', Value of Water Research Report Series No. 17 (Deflt: UNESCO-IHE, 2005).

19 Erik Ansink, 'Refuting Two Claims About Virtual Water Trade', 69 Ecological Economics 2027-2032 (2010); David A. Seekell, Paolo D’Odorico and Michael L. Pace, 'Virtual Water Transfers Unlikely to Redress Inequality in Global Water Use', 6 Environmental Research Letters 024017 (2011); Arjen Y. Hoekstra and P.Q. Hung, 'Virtual Water Trade: A Quantification of Virtual Water Flows between Nations in relation to International Crop Trade', Value of Water Research Report Series no. 11 (Delft: UNESCO-IHE, 2002). 
would have to increase dramatically and realign itself from water-rich to water-poor countries in order to begin to reduce inequality in distribution of water resources.

Other researchers rate more highly the impact of virtual water trade on a regional level. López-Gunn and Llamas report that while only $4 \%$ of global agricultural virtual water is imported by arid or semi-arid countries, this is still a significant amount of water. The Middle East and North Africa regions import more virtual water than the annual average flow of the Nile River. ${ }^{21}$

Le Vernoy and Messerlin used economic modeling of international trade to show that water availability is one of several production factors that influence international trade. ${ }^{22}$ Even when not motivated by sustainability concerns, countries may decide to import virtual water as a matter of national policy in order to relieve food and water security concerns, while not creating dependence on another country. ${ }^{23}$ Such trade may also offer a way to defer water conservation measures and charging for water at home.

\section{Virtual water and international trade law}

International trade in virtual water raises issues under the WTO, many of which are familiar in other contexts. This article focuses mainly on trade in agriculture, as the dominant and best understood form of virtual water transfer. Virtual water transfer through trade in non-agricultural products, such as cotton apparel and canned food, will invoke other aspects of the international trade regime.

This preliminary investigation of international trade law applicable to virtual water trade focuses on tariff reduction, subsidy reform, water efficiency regulations, and water labeling. The most relevant WTO agreements are the General Agreement on Tariffs and Trade 1994 (for non-agricultural products), the Agreement on Agriculture, the Agreement on Subsidies and Countervailing Measures, and the Agreement on Technical Barriers to Trade. ${ }^{24}$

One of the main issues in the Doha round of trade negotiations is agricultural reform, which includes improved market access (e.g. through reducing tariffs) and reductions in trade-distorting subsidies. ${ }^{25}$ Both tariff reduction and subsidy elimination could affect trade in virtual water.

One of the central points of this article is that trade liberalization alone will not optimize virtual water trade to address water-scarcity problems. Putting a price on water is essential. Otherwise, trade liberalization could contribute to water-scarcity problems, as discussed below. Other means that focus on managing the demand for

21 Elena López-Gunn and M. Ramón Llamas, 'Can Human Ingenuity, Science and Technology Help Solve the World's Problems of Water And Food Security?', in Luis Martínez-Cortina, Alberto Garrido, and Elena López-Gunn (eds), Re-thinking Water and Food Security: Fourth Botín Foundation Water Workshop (London: Taylor \& Francis, 2010).

22 Le Vernoy and Messerlin, above n 17.

23 John Anthony Allan, 'Virtual Water - the Water, Food, and Trade Nexus: Useful Concept or Misleading Metaphor?', 28 Water International 4-11 (2003).

24 General Agreement on Tariffs and Trade (GATT), 15 April 1994, 1867 U.N.T.S. 187 (1994); Agreement on Agriculture, 15 April 1994, 1867 U.N.T.S. 410; Agreement on Subsidies and Countervailing Measures (SCM Agreement), 15 April 1994, 1869 U.N.T.S. 14; Agreement on Technical Barriers to Trade (TBT Agreement), 15 April 1994, 1868 U.N.T.S. 120 (1994). 
water include water efficiency regulations and water labeling, either water intensity labeling or labeling of water source, as for fossil aquifers. Each of these approaches may implicate international trade law.

\section{REDUCING AGRICULTURAL TARIFFS}

Part of the mandate of the Doha round of trade negotiations is the reduction of tariffs for agricultural products. This has the potential to increase trade in virtual water, and thereby address water efficiency and distribution issues. However, in practice, tariff reduction alone may not result in optimization of global water resources because of water's small role in production and trade decisions, potential water inefficiencies arising from comparative advantage, and economic and financial barriers to participation in international agricultural trade by developing countries. It could, unintentionally, contribute to water-scarcity problems, so long as water does not have a price as a commodity.

National- and regional-level studies support the idea that trade liberalization can increase trade in virtual water. In a study of five countries in Latin America (Argentina, Brazil, Chile, Mexico, and Peru), Niemeyer and Garrido found that trade liberalization increased trade in agricultural goods. ${ }^{26}$ If current trade in virtual water is creating global water savings, increasing trade volume through reducing tariffs and other barriers to trade may further improve efficiency and, it is argued, address water scarcity at both the national and global levels. ${ }^{27}$

There is evidence that liberalizing trade in virtual water, however, may not alleviate water scarcity on the national level. A study of trade liberalization and virtual water in China found that following accession to the WTO in 2001, China cut tariff rates on agricultural goods and subsequently imports of grains and soybeans and exports of vegetables increased. ${ }^{28}$ However, this did not result in a large net change in water consumption, because increased vegetable exports required more water for irrigation, counteracting the water savings from importing grains. This is in line with other evidence of water-scarce countries exporting water-intensive agricultural products. The WTO 2010 World Trade Report reports water resource overuse and depletion in Thailand and Kenya as a result of irrigation of export crops (rice and flowers, respectively), and a potential problem in Brazil where the government subsidizes fruit exporters through artificially low water pricing. ${ }^{29}$

On the global level, several economic models have attempted to predict the effect of reducing tariffs on savings in water globally. A 2008 study by Berrittella et al.

26 Insa Niemeyer and Alberto Garrido, 'Latin American Agricultural Trade: The Role of the WTO in Sustainable Virtual Water Flows', European Association of Agricultural Economists 2011 International Congress (Zurich: EAAE, 30 August to 2 September 2011).

27 Arjen Y. Hoekstra, 'The Global Dimension of Water Governance: Nine Reasons for Global Arrangements in Order to Cope with Local Water Problems', Value of Water Research Report Series No. 20 (Delft: UNESCO-IHE, 2006); Le Vernoy and Messerlin, above n 17.

28 Yongsong Liao, Charlotte de Fraiture, and Mark Giordano, 'Global Trade and Water: Lessons from China and the WTO', 14 Global Governance 503-521 (2008). The study also pointed out the importance of considering regions within-country: most grains in China are produced in the overexploited northern region, so import of these products may be particularly important to ensuring water and food security. World Trade Organization, above n 15; Hoekstra and Chapagain, above n 9. 
modeled water use in representative developed and developing countries under various agricultural tariff reduction scenarios of up to $75 \%$ tariff reduction. The model predicted that trade liberalization would enhance current patterns of trade, with countries that currently substantially export virtual water exporting even more, and countries that currently substantially import virtual water importing more. However, the model also predicted that changes in national water use under all scenarios would be small, not exceeding $10 \%$. Moreover, the authors found no clear relationship between absolute water scarcity and change in use under the tariff reduction scenarios, though trade liberalization would incidentally reduce export of virtual water from some of the world's most water-scarce regions: the Middle East, South Asia, and North Africa. ${ }^{30}$

An earlier study by Ramirez-Valejo and Rogers, which modeled the impact of removal of all barriers to trade, including tariffs as well as all agricultural subsidies, resulted in similar predictions, that trade liberalization would lead to increases in virtual water export from USA and Latin America, and increases in virtual water import to Asia, sub-Saharan Africa, and the former USSR. Like the results of the Berrittella model, this study found no correlation between virtual water import and local water scarcity: trade liberalization did not necessarily lead water-poor countries to import more virtual water. ${ }^{31}$ Both studies suggest that trade liberalization through reduction of agricultural tariffs will not adequately address problems of water resource scarcity and uneven distribution.

There are several reasons why tariff reductions alone might not adequately improve efficiency in the use of water, the uneven distribution of water resources, or the problems of water scarcity. Water is not a primary driver of production and trade decisions, in part because it is either not priced or underpriced, and because it can be eclipsed by other factors, including political pressure.

Because water is usually underpriced or not priced at all, water scarcity does not send a strong signal to producers or investors. In a study of Spain, Garrido et al. found that the volume of virtual water exports did not respond to changes in water scarcity. ${ }^{32}$ Other factors, such as the availability of arable land, labor costs, access to technology, national food policies, and international trade agreements send much stronger signals. ${ }^{33}$ Even cultural values can override water considerations in determining production and trade decisions. Australia and USA export substantial quantities of irrigated agricultural products at prices equal to or lower than the cost of production. This is done for political reasons derived from both the lobbying power of agribusiness and from the input of cultures that place a non-economic value on maintaining a strong agricultural sector. ${ }^{34}$

30 Maria Berrittella, Katrin Rehdanz, Richard S.J. Tol, and Jian Zhang, 'The Impact of Trade Liberalization on Water Use: A Computable General Equilibrium Analysis', 23 Journal of Economic Integration 631-655 (2008).

31 J. Ramirez-Vallejo and P. Rogers, 'Virtual Water Flows and Trade Liberalization', 49 Water Science and Technology 25-32 (2004).

32 Alberto Garrido et al., 'Economic Aspects of Virtual Water Trade: Lessons from the Spanish Case', in Luis Martínez-Cortina, Alberto Garrido, and Elena López-Gunn (eds), Re-thinking Water and Food Security: Fourth Botín Foundation Water Workshop (London: Taylor \& Francis, 2010) 145.

33 López-Gunn and Llamas, above n 21; Ansink, above n 19; Seekell, D’Odorico, and Pace, above n 19.

34 Andrew Biro, 'Water Wars by Other Means: Virtual Water and Global Economic Restructuring', 12 Global Environmental Politics 86-103 (2012). 
According to the theory of comparative advantage, countries will export products that are relatively cheaper or more efficient to produce than other products, even if their trading partners can produce them even more cheaply. Likewise, countries will import products for which they have a comparative disadvantage, even if they could produce those products more cheaply at home. Applied to trade in virtual water, comparative advantage means that even if water resources are adequately priced, water-poor countries with a comparative advantage in water-intensive products may still trade them to water-rich countries with a comparative disadvantage in those products, and vice versa. ${ }^{35}$ For example, countries like Afghanistan and Malawi, which are relatively water-poor but have large amounts of arable land, may have a comparative advantage in water-intensive goods and therefore will export virtual water. Similarly, water-rich countries like Norway and Switzerland with a comparative advantage in non-water-intensive goods-because of a lack of arable land and of well-developed non-agricultural industries-may import virtual water. ${ }^{36}$ Technology can also give countries a comparative advantage in water-intensive products, even if they are water-poor. ${ }^{37}$ These considerations are critical in global agriculture.

Developing countries may have trouble participating in international virtual water trade. In a study of the virtual water trade network, Konar et al. found that $80 \%$ of global virtual water in trade flowed along only $4.2 \%$ of the links in the global network. ${ }^{38}$ This created what they termed a 'weighted rich club phenomenon' in which dominant developed countries participated in large-volume trade, whereas small countries traded relatively small volumes on the 'trade periphery. ${ }^{39}$

Virtual water transfer only provides a means for redistributing water resources and ensuring food security if water-poor countries can afford to import waterintensive resources. However, many water-poor countries are also cash-poor and cannot afford to import virtual water in sufficient quantities. ${ }^{40}$ At the same time, developing countries may be limited in their virtual water exports, as developing country producers may be unable to compete in international markets. International agribusiness operations and farmers based in developed countries have access to resources that developing country producers may lack, such as low-cost transportation, more efficient technology, relationships with global trading corporations, government subsidies, and insurance (government or private) against droughts or other loss. ${ }^{41}$ Developing country producers may find it impossible to compete with these lowcost agricultural products. Moreover, facilitating entry of low-cost agricultural products to the domestic market in developing countries may affect local producers, decreasing their profits so that they are unable to invest in the improvements that

Dennis Wichelns, 'The Policy Relevance of Virtual Water can be Enhanced by Considering Comparative Advantages', 66 Agricultural Water Management 49-63 (2004); Le Vernoy and Messerlin, above n 17; Seekell, D'Odorico and Pace, above n 19.

36 Ansink, above n 19.

37 Garrido et al., above n 32.

38 Konar et al., above n 14.

39 Ibid, at 16.

40 For example, López-Gunn and Llamas, above n 21; Seekell, D’Odorico and Pace, above n 19.

41 Allan, above n 12; Munir A. Hanjra and M. Ejaz Qureshi, 'Global Water Crisis and Future Food Security in an Age of Climate Change', 35 Food Policy 365-377 (2010). 
might eventually enable them to compete in the international food market. ${ }^{42}$ In this way, reducing tariffs could run counter to improving water use efficiency globally, by closing off the global market to potentially important participants.

Most importantly, trade liberalization through reducing tariffs has the potential to contribute to the water-scarcity problems in this century unless it is taken in conjunction with efforts to remove harmful subsidies for water which encourage inefficient use and to put a price on water, with appropriate exceptions for implementing a human right to water. If tariffs are reduced or eliminated on agricultural produce, market access should indeed improve. This should result in greater agricultural trade and potentially greater agricultural production. This is turn will increase demand for water, irrespective of whether water is extracted and used efficiently or whether water-intensive crops are grown in water-poor countries. This scenario could add to local or larger scale problems of water scarcity. While such a result is surely not automatic, the scenario does caution that trade liberalization needs to proceed in tandem with analyses and consideration of the projected problems of water scarcity.

\section{ELIMINATING TRADE-DISTORTING AGRICULTURAL SUBSIDIES}

Agricultural subsidies have the potential to distort trade in virtual water and thereby affect global water efficiency and distribution. It is important to recognize that even apparently non-water-related agricultural subsidies can affect trade in water-intensive agricultural products by lowering the price of such products on international and domestic markets, and by encouraging increased production which can contribute to unsustainable water utilization.

The Doha round of trade negotiations includes reducing trade-distorting agricultural subsidies. Both the Agreement on Agriculture and the Agreement on Subsidies and Countervailing Measures regulate agricultural subsidies that distort trade, including export subsidies and domestic support. The Agreement on Agriculture limits the aggregate amount of domestic support that each member country can provide that falls into the category of support deemed to have the greatest impact on trade (the so-called Amber box). This is subject to certain exemptions, the so-called Green and Blue boxes. The Agreement on Subsides and Countervailing Measures (SCM) regulates the use of subsidies and countervailing duties, which are applied to imports to offset injury to domestic industry caused by the subsidized imports. ${ }^{43}$ Domestic support subsidies are actionable under the SCM only if they are specific to a particular enterprise or region and cause adverse effects to the domestic interests of another Member State.

Much of the discussion about agricultural subsidies and water use centers on irrigation subsidies, which are a form of domestic support. Irrigation subsidies may be a significant driver of inefficient water use leading to water scarcity. They can also disrupt any water-related price signal, making it more difficult for scarcity factors to

42 Garrido et al., above n 32.

43 For analysis of the application of the Agreement on Agriculture and the Agreement on Subsidies and Countervailing Measures to agricultural products, see Nathalie Bernasconi-Osterwalder, 'Water, Agriculture, and Subsidies in the International Trading System', in Edith Brown Weiss, Laurence Boisson de Chazournes, and Natalie Bernasconi-Osterwalder (eds), Fresh Water and International Economic Law (Oxford: Oxford University Press, 2005) 207-231. 
influence virtual water trade. However, such subsidies may not be subject to controls under either the Agreement on Agriculture, which exempts 'water supply facilities, dams, and drainage systems', or the Agreement on Subsidies and Countervailing Measures, which exempts 'general infrastructure' and which requires injury to a domestic industry of an importing State. Such market distortion may be difficult to show in the case of water-related subsidies. ${ }^{44}$ It may also be difficult to show that water-related subsidies meet the definition and specificity requirements for actionable subsidies under the SCM. ${ }^{45}$

All forms of agricultural subsidies, including subsidies not directly involving irrigation, however, can affect trade in virtual water. Both export subsidies and domestic production subsidies can lower global prices of agricultural products even below the cost of production. Developed countries are primary users of such subsidies. For example, the European Union exports wheat at $50 \%$ of its production costs, driving down global wheat prices, whereas USA sends heavily subsidized maize, wheat, and soybean onto the global market. ${ }^{46}$ These artificially low-priced agricultural products can affect domestic producers in countries that do not employ such strong domestic agricultural support, particularly developing countries. Notably, this impact on the domestic agricultural market in other countries would constitute an adverse effect on the interests of another member, within the meaning of the SCM Agreement. Agricultural subsidies which affect international trade and foreign domestic markets in this way, therefore, could be actionable under the SCM Agreement, provided they go beyond general infrastructure. Moreover, many such trade-distorting agricultural subsidies fall within the Amber box under the Agreement on Agriculture and are therefore counted as part of a country's total aggregate measurement of support.

Elimination of these subsidies would most likely increase the price of waterintensive agricultural products on the global market. However, it is difficult to judge the extent of the effect. In a 2004 study, Ramirez-Vallejo and Rogers simulated removal of all trade barriers and agricultural subsidies, including producer and consumer subsidies. They found that such liberalization would lead to increases in the prices of cereals and meat products on the global market. ${ }^{47}$ However, a 2005 FAO modeling study focusing on irrigated agricultural products showed only a small (2-4\%) increase in the price of internationally traded irrigated agricultural products, with a correspondingly small $(<1 \%)$ increase in the annual rate of growth of developing country agricultural sectors. ${ }^{48}$ In these models, tariff reductions, which effectively lower the price of internationally traded agricultural goods, may have counteracted some of the effects of subsidy reform. It is difficult to judge the extent

Ibid. Notably, in its required subsidy notifications under the Agreement on Agriculture, USA has in the past listed irrigation subsidies, such as for infrastructure, as 'Amber Box' subsidies, subject to limits and scheduled reductions, but it has not included water provided to agriculture producers at below market rates. Ibid, at 219 .

45 Ibid.

46 Gerald A. Cornish and Sara Fernandez, 'Agricultural Trade Liberalization: Implications for Irrigated Agriculture', IPTRID Issue Paper no. 5 (Rome: FAO, 2005).

47 Ramirez-Vallejo and Rogers, above n 31.

48 Cornish and Fernandez, above n 46. 
of the impact subsidy elimination alone would have on international virtual water trade.

If subsidy reform did increase the international price of water-intensive agricultural products, it could facilitate access to the international market for developing country producers. Even if, together with tariff reduction, subsidy reform did not result in a large absolute increase in the international price of agricultural products, it could still help level the playing field between developing country and developed country producers. However, subsidy reform could also limit the ability of waterpoor developing countries to import agricultural products.

An additional problem associated with subsidy reform is one of implementations. Under the SCM Agreement, the primary remedy for trade-distorting subsidies is imposition of countervailing duties by an importing country that can show harm to its domestic industry. A country that chose to subsidize in a way that is inconsistent with the WTO rules could still produce cheap agricultural produce and export it to countries that do not use countervailing duties, either because they do not produce the product domestically and therefore are not in competition with the subsidizing country, or because they are highly in need of the subsidized agricultural produce. ${ }^{49}$

\section{REGULATING WATER EFFICIENCY}

Regulations that promote efficient use of water could be used to help manage international trade in virtual water. National or subnational water efficiency standards that apply to both domestically produced and imported products would close off those markets to products which did not meet such standards, putting pressure on producers to use more water-efficient technology, or relocate to more waterefficient locations. Regulations should be developed so as to minimize administrative costs.

A regulatory system for water efficiency would require methods for accurately and consistently measuring virtual water content across the life cycle of different products. It would have to set a water efficiency threshold at a high enough level to allow sufficient production to meet the need, but a low enough level to put some pressure on producers to be more water efficient. In this, water could be particularly problematic, since all goods require some amount of water, for which in almost all cases there is no substitute. Finally, implementation of virtual water efficiency regulations would require fair and continuous monitoring to ensure that products coming from a multitude of countries and situations met water efficiency standards.

A focus on water-efficient technology or practices rather than absolute virtual water content could make implementation easier. However, such a system would have no effect on shifting production to water-efficient production regions, as even producers in inefficient regions could meet the regulatory standards as long as they used qualifying technology and/or practices. Alternatively, some of the evaluation and implementation costs of water efficiency regulation could be alleviated through reliance on self-reporting by producers with some mechanism for third-party confirmation. 
Water efficiency regulations could also raise problems under the WTO. Both the General Agreement on Tariffs and Trade (GATT) and the Agreement on Technical Barriers to Trade (TBT) require WTO Members to ensure that imported products are accorded 'treatment no less favourable than that accorded to like products' of national origin and to like products imported from other countries. ${ }^{50}$

In determining whether products are 'like', the WTO dispute settlement bodies look to whether they are in a 'competitive relationship in the marketplace', relying on such factors as end use, consumer preference, tariff classification, and physical properties of the product. ${ }^{51}$ Typically, such determinations are made on the basis of characteristics inherent in the product as traded-product-related distinctions. However, regulations based on virtual water content constitute a type of non-product-related process and production method distinction (npr-PPM). Such distinctions are based on production characteristics that do not affect the final product. For example, a loaf of bread produced using 1200 liters of water looks, smells, and tastes no different from a loaf of bread produced using 500 liters. ${ }^{52}$ One might conceivably argue, though subject to much debate, that non-product-related process and production method distinctions (npr-PPM) such as virtual water content could provide grounds to find that otherwise identical products are not 'like', particularly where they influence consumer preference. ${ }^{53}$ However, in previous cases, such as US-Tuna II, the Panel and Appellate Body have treated products differing only in npr-PPM factors as like products. ${ }^{54}$ If this trend continues, then regulation on the basis of virtual water content could be judged discriminatory between 'like' products. Where such discrimination disproportionately affects imported products from certain countries - which, given discrepancies in water efficiency of agricultural production in different countries, is not unlikely - this might constitute de facto discrimination against those countries. ${ }^{55}$

In cases of de facto discrimination under the TBT, the dispute settlement bodies of the WTO must look to whether the discrimination results 'exclusively from a legitimate regulatory distinction rather than reflecting discrimination against the group of imported products' to determine whether it constitutes 'less favourable treatment', which is prohibited under TBT Article 2.1. ${ }^{56}$ Therefore, even if identical products

50 TBT Agreement, Article 2.1; GATT arts. I.1, III.4.

51 WTO Appellate Body Report, European Communities - Measures Affecting Asbestos and Products Containing Asbestos (EC - Asbestos), WT/DS135/AB/R, adopted 5 April 2001; WTO Appellate Body Report, United States - Measures Affecting the Production and Sale of Clove Cigarettes (US - Clove Cigarettes), WT/DS406/AB/R, adopted 24 April 2012, para 110.

52 An average $750 \mathrm{~kg}$ loaf of bread has a water footprint of 1200 liters; while a loaf of bread baked with Dutch wheat has a water footprint of 460 liters, considering only water content of the flour used. Data taken from Water Footprint Network Product Gallery, available at http://www.waterfootprint.org/ ?page $=$ files/productgallery (accessed 16 July 2013).

53 See, e.g., Appellate Body Report, US - Clove Cigarettes, above n 51, para 137 (affirming that consumer preferences should be considered in 'like-product' determinations).

54 In this case, tuna caught in Mexican waters by methods involving setting nets around pods of dolphins was judged 'like' tuna caught by 'dolphin-safe' methods. WTO Appellate Body Report, United States Measures Concerning the Importation, Marketing and Sale of Tuna and Tuna Products (US - Tuna II), WT/ DS381/AB/R, adopted 13 June 2012.

55 Appellate Body Report, US - Clove Cigarettes, above n 51 (stating that even facially neutral regulations can result in de facto discrimination if they disproportionately affect imports from a Member country). Ibid; Appellate Body Report, US - Tuna II, above n 54. 
with different virtual water contents are determined to be like products under the TBT, a regulating country could still be in conformity with its obligations under the TBT as long as the regulation is based on a legitimate regulatory distinction.

GATT Article III has also been interpreted to cover de facto discrimination, where formal regulatory equality creates conditions less favourable to imported products. ${ }^{57}$ However, even if water efficiency regulations were determined to constitute a violation of this provision, they might still be justified by one of the exceptions listed in Article XX of GATT. Article XX(b) creates an exception for measures 'necessary to protect human, animal or plant life or health' and $\mathrm{XX}(\mathrm{g})$ creates an exception for measures 'relating to the conservation of exhaustible natural resources if such measures are made effective in conjunction with restrictions on domestic production or consumption'. The latter is an easier standard to meet. Even if the measures are qualified under one of the exceptions, they would then also have to conform to the requirements of the Article XX chapeau. This requires that they not be applied in a manner which would constitute 'a means of arbitrary or unjustifiable discrimination between countries where the same conditions prevail, or a disguised restriction on international trade'. A water efficiency regulation would need to be designed with these requirements in mind-i.e. it should use the same methods for evaluating virtual water content for products imported from all countries and for domestic products, and it should ensure that regulations are applied fairly and transparently. 58

\section{INITIATING WATER LABELING}

Water labeling would give consumers information about the 'water footprint' of a given good or product. It offers one approach to inducing more efficient use of water and to limiting unsustainable exploitation of water resources. Water labeling in the context of the trade in virtual water would potentially make water content a factor in demand for certain products. Labels give consumers especially valuable information when they relate to attributes not immediately apparent in the final product. Consumers can then draw on environmental, social, and other values in making purchasing decisions, and put pressure on producers to conform to these values. Little has been written about the trade implications of virtual water labels. However, other forms of environmental labels, such as carbon labels, are increasingly subject to discourse both within and outside of the WTO, much of which is applicable to virtual water labels as well. The question of environmental labeling is included in the agenda of the Committee on Trade and the Environment in the WTO Doha negotiations. ${ }^{59}$ and Internal Sale of Cigarettes (Dominican Republic - Import and Sale of Cigarettes), WT/DS302/AB/R, adopted 19 May 2005.

58 See WTO Appellate Body Report, United States - Import Prohibition of Certain Shrimp and Shrimp Products (US - Shrimp), WT/DS58/AB/R, adopted 6 November 1998; WTO Appellate Body Report, United States - Import Prohibition of Certain Shrimp and Shrimp Products - Recourse to Article 21.5 of the DSU by Malaysia, WT/DS58/AB/RW, adopted 21 November 2001. 


\section{A. Potential effectiveness of water labeling}

In considering water labeling, experience with environmental labels or ecolabels is relevant. Environmental labels have been effective in enabling consumer pressure to manage producer behavior. For example, rising public concern about dolphin-killing in the late 1980s and early 1990s led USA and other countries to create 'dolphin-safe' tuna labels, to allow consumers to purchase according to their values, sending a price signal to producers and ultimately leading to a change in typical sourcing practices for canned tuna. ${ }^{60}$ The effectiveness of labels as a means of market manipulation depends on several factors including nature and reliability of information provided, availability of alternatives, and consumer awareness of, and concern over, the issue at stake.

For labels to be effective, the information provided must be understandable, credible, and accurate. Consumers will not base purchasing decisions on information they do not deem to be credible. There is also a danger that consumers could make choices based on incomplete information or labels they do not fully understand, which could create unwanted market distortion. ${ }^{61}$ Third-party labeling standards and regulations can help ensure accuracy, clarity, and credibility of information. However, labeling standards impose a cost on producers, which can be particularly problematic for smaller producers and developing country producers. ${ }^{62}$

Developed country consumers may be more aware of and willing to spend money to address issues such as water scarcity than their developing country counterparts. ${ }^{63}$ If so, labeling may contribute to managing virtual water transfers to developed countries, but not to developing countries. However, given the current primacy of developed countries in virtual water trade, as discussed above, this will only be a problem if developing countries are able to increase their virtual water imports.

In theory, labeling could reduce demand for certain products in developed countries, lowering international prices. ${ }^{64}$ This could negatively impact developing country producers, which would struggle to compete on the international market with both high water efficiency products - because of labeling costs and technology costs-and low water efficiency products-because of depressed prices from reduced developed country demand.

There are different possible types of virtual water labels, which will impact the effect of a labeling scheme as well as its compatibility with international trade law. These include: (1) virtual water content labels, which list the virtual water content of the product; (2) virtual water ratings, which award water efficiency ratings to products depending on their virtual water content relative to optimal virtual water

60 See Mark A. Cohen and Michael P. Vandenbergh, 'The Potential Role of Carbon Labeling in a Green Economy', 34 Energy Economics S53-S63 (2012).

61 Ilona Cheyne, 'Proportionality, Proximity and Environmental Labelling in WTO Law', 12 Journal of International Economic Law 927-952 (2009).

62 Jane Kloeckner, 'The Power of Eco-Labels: Communicating Climate Change using Carbon Footprint Labels Consistent with International Trade Regimes under the WTO', 3 Climate Law 209-230 (2012).

63 See Shane Baddeley, Peter Cheng, and Robert Wolfe, 'Trade Policy Implications of Carbon Labels on Food', 13 The Estey Centre Journal of International Law and Trade Policy 59-93 (2012) (suggesting that developed country consumers are more likely to respond to carbon labels because they are more aware of and concerned about global warming). 
content for that product category; (3) virtual water efficiency threshold labels, which affirm that the product meets a certain standard of virtual water efficiency; and (4) virtual water source labels, which identify whether water used in production of a product comes from a non-renewable fossil aquifer. The last label addresses an issue specific to fresh water. Since fossil aquifers do not recharge, using the water now means that it is not available to future generations. If criteria could be developed for equitable or sustainable exploitation of the aquifer, labels could reflect these.

The different types of labels may have different levels of effectiveness, depending on the goal. Virtual water content labels may provide a means of raising awareness about the different water content of different types of products, and encourage shifts away from water-intensive categories of products, like meats and cheeses. However, such labels may be less effective at influencing choices within product categories, as the differences between virtual water content of different products is so great as to potentially overwhelm differences between brands. For example, $1 \mathrm{~kg}$ of beef contains on average 15,400 liters of virtual water, while $1 \mathrm{~kg}$ of tomatoes contains 200 liters. ${ }^{65}$ A rating system or water efficiency threshold system might be more suited to encouraging comparison within product categories-which could have the most effect on shifting production of certain products to more water-efficient locationsbut would not allow comparison between types of products. Virtual water source labels would allow consumers to choose either types of products or specific brands which use water from renewable sources, regardless of amount of water used.

Like direct virtual water regulation, virtual water labeling systems need to work out standardized, fair, accurate methods to measure virtual water content across the life cycle of a product-a potentially difficult and costly task. Rating systems and water efficiency threshold systems also need to set qualifying levels for the different ratings and the threshold, respectively. Because of the administrative costs involved, labeling systems may need to focus on products with the potential to make the most difference in international virtual water trade. These might include water-intensive products that have readily available substitutes that are less water-intensive, which consumers are likely to use, and products that vary greatly in virtual water content depending on production method or location, which lets consumers choose lower water intensity products of the same type. ${ }^{66}$

Virtual water labels can be voluntary or non-voluntary. Mandatory labels impose costs on all producers who seek to enter a market, which can exclude smaller firms or developing country producers. ${ }^{67}$ However, even voluntary labels can have the effect of disadvantaging developing country producers in environmentally conscious markets, unless they can implement the labels.

Many well-known and commonly used labeling systems in the world are promulgated and managed by non-government entities. These include Fairtrade

Data taken from Water Footprint Network Product Gallery, available at http://www.waterfootprint.org/ ?page $=$ files/productgallery (accessed 16 July 2013).

66 See Cohen and Vandenbergh, above n 60, for a discussion of the types of products which should be labeled in the context of carbon labeling. Le Vernoy and Messerlin also argue that a virtual water labeling system should be limited to a few water-intensive products to avoid excessive administrative costs. Le Vernoy and Messerlin, above $n 17$. 
International, the International Federation of Organic Agriculture Movements, and the Carbon Trust, which operates the Carbon Reduction Label adopted by supermarkets in the UK. ${ }^{68}$ In the world of environmental labeling, the proliferation of labeling bodies and the absence of over-arching global coordination have led to multiple, overlapping, and sometimes conflicting standards which have the potential to undermine each other's legitimacy and effectiveness. ${ }^{69}$ A multitude of standards could also increase the obstacles to small producers and developing country producers which lack capacity to either participate in the development of standards or meet the multiple overlapping requirements for different markets.

The International Social and Environmental Accreditation and Labelling Alliance (ISEAL) has stepped forward as an umbrella organization to help coordinate the practices and processes of these various organizations, and push for official government adoption of their labeling standards. ${ }^{70}$ This organization could provide a framework for developing an international standard for virtual water labeling.

The International Organization of Standardization (ISO), a non-governmental group composed of national standardizing bodies, could also provide a home for a global virtual water labeling standard. ${ }^{71}$ The ISO develops and maintains international environmental standards in its ISO 14000 series. ISO 14024 sets out principles and procedures for environmental labeling systems. It stipulates that labeling criteria should consider the entire life cycle of the product and should highlight significant differences that make certain products environmentally preferable to others in the same product category. Labeling criteria should also be set at attainable levels, developed through a participatory process, and subject to periodic review and revision. ${ }^{72}$ Based in part on these criteria, the ISO has developed a specific standard for carbon footprint labeling. ${ }^{73}$ Following this model, it could also develop specific standards for virtual water labeling.

\section{B. Water labeling and international trade law}

Both government and private water labeling systems potentially raise questions under the WTO. The issues depend on the standardizing body, the nature of the regulation or requirement, and the type of labeling system used.

Government regulations which promulgate or facilitate labeling standards raise some of the same issues as direct regulations of virtual water content under the TBT Agreement and the GATT. The type of issue raised depends on the nature of the labeling regulation, whether it is voluntary or mandatory, and what type of labeling system it employs.

Steven Bernstein and Erin Hannah, 'Non-State Global Standard Setting and the WTO: Legitimacy and the Need for Regulatory Space', 11 Journal of International Economic Law 575-608 (2008).

69 Baddeley, Cheng and Wolfe, above n 63; Bernstein and Hannah, above n 68.

70 Ibid.

71 Ibid.

72 ISO, Environmental labels and declarations: How ISO standards help (ISO 2012).

73 ISO/TS 14067:2013, Greenhouse Gases - Carbon Footprint of Products - Requirements and Guidelines for Quantification and Communication, available at http://www.iso.org/iso/catalogue_detail? csnumber $=59521$ (accessed 7 August 2014). 
Under the TBT Agreement, for a measure to be considered a 'technical regulation', compliance must be mandatory. ${ }^{74}$ However, even ostensibly 'voluntary' labels could be considered 'mandatory' if their use is a pre-requisite to entry to a market, or they preempt equivalent alternatives. For example, in US-Tuna II, the Appellate Body found that US provisions on 'dolphin-safe' labeling for canned tuna were inconsistent with article 2.1 of the TBT agreement. It found that these labels could be characterized as technical regulations because, although producers could sell products without the label, they could not use any other label containing terms related to dolphins, which limited their ability to compete in an environmentally conscious market. ${ }^{75}$ Similarly, under the GATT, any law or regulation that affects the conditions of competition, even regulations which provide some measure of private choice, is subject to the requirement that imported products be treated no less favorably than domestic like products or products from other countries. ${ }^{76}$ Given that the purpose of virtual water labeling is to modify the conditions of competition so as to encourage purchase of less water-intensive products, even 'voluntary' labeling schemes that accomplished this goal might come within the scope of this provision.

Like direct regulations of virtual water content, government labeling regulations which fall within the scope of the TBT Agreement or GATT must not treat imported products less favorably than like domestic products or like products imported from other countries. Labeling schemes that employ a virtual water content or rating system may not raise issues here at all. Where such schemes apply the same requirement to all products - that they include on the packaging a rating or virtual water content - and employ identical and fair evaluation and labeling requirements across all like products, regardless of country of origin or production method, they do not discriminate between products, even where similar products with different virtual water content are considered 'like'. Threshold-type labels, which would only be available to products meeting a certain standard of water efficiency, would risk being considered discriminatory under the TBT and GATT Article III. In US-Tuna II, the Appellate Body found that 'dolphin-safe' labels, only available to products meeting a certain standard based on fishing methods, resulted in de facto discrimination against Mexican tuna producers, the majority of which practice a fishing method which does not meet the standard, because such producers were disadvantaged in the American market, in which consumers showed a preference for 'dolphin-safe' products. $^{77}$ Similarly, if producers from certain countries were disproportionately unable to meet water efficiency standards-which is likely given the impact of climate differences on water efficiency in production-those countries could claim de facto discrimination under the TBT, and potentially also the GATT. Virtual water

76 WTO Appellate Body Report, Korea - Measures Affecting Imports of Fresh, Chilled, and Frozen Beef (Korea - Various Measures on Beef), WT/DS169/AB/R, adopted 10 January 2001. In this case, the Appellate Body found that Korean regulations prohibiting imported and domestic beef from being sold in the same section of a store constituted a violation of GATT Article III.4, because they resulted in many small retailers deciding to stock only domestic beef, reducing imported beef s access to the market. Appellate Body Report, US - Tuna II, above n 54. 
source labels could similarly create situations of de facto discrimination against countries dependent on fossil aquifers.

As discussed above, a finding of de facto discrimination only indicates a violation under the TBT if the detrimental impact does not stem from a legitimate regulatory distinction. In the US-Tuna II case, the Appellate Body found that the de facto discrimination constituted treatment less favourable because USA employed different labeling requirements for tuna caught within the Eastern Tropical Pacific region (ETP) as opposed to tuna caught outside that region, and because the distinction between methods was not 'calibrated' to the risks to dolphins from different fishing methods in different regions. ${ }^{78}$ The requirement that labeling distinctions be calibrated to the regulatory objective should be borne in mind in the design of a virtual water labeling system, particularly one that employs a virtual water efficiency threshold system.

Though the Appellate Body did not address GATT Article III questions in the US-Tuna II case, virtual water labeling resulting in de facto discrimination would likely be treated similarly to other types of regulation, as discussed above. If labeling systems were found to constitute less favourable treatment, they would still be eligible for exception under the GATT Article $\mathrm{XX}(\mathrm{b})$ and $(\mathrm{g})$ exceptions, as long as they were not found to be 'arbitrary or unjustifiable discrimination' or 'a disguised restriction on international trade'.

Private virtual water labeling systems would not be directly subject to trade disciplines under the GATT or TBT unless officially adopted by a national government. However, government regulations implementing or facilitating such systems, such as laws or regulations prohibiting alternative systems or subsidizing producers or retailers who adhere to such systems, would be subject to claims under the GATT, TBT Agreement, or, depending on the type of regulation, the SCM Agreement. Government procurement schemes which favor products meeting privately promulgated standards could also fall within the scope of the plurilateral Government Procurement Agreement when adopted by signatories of that agreement. ${ }^{79}$ In addition, countries have obligations relevant to private standards under Article 4.1 of the TBT Agreement, which mandates that they take reasonable measures to ensure that non-government standardizing bodies within their territory comply with the Code of Good Practice included as Annex 3 of the Agreement. This includes requirements that the standardizing body accord imported products treatment no less favourable than that accorded to like products of national origin and like products originating in other countries, and that standards are not applied with a view to creating unnecessary obstacles to international trade.

79 Several governments have adopted policies to consider non-government environmental standards in their procurement decisions. In 2004, the EC published a handbook advising member countries to consider international standards, including nongovernment standards, in developing green procurement policies. European Commission, Buying Green! A Handbook on Environmental Public Procurement (Luxembourg: Office for Official Publications of the European Communities, 2004). See also Bernstein and Hannah, above $\mathrm{n} \mathrm{68}$, for a description of non-government environment standards in government procurement policies. 
The TBT Agreement also requires member countries to use 'relevant international standards' as a basis for their technical regulations (Article 2.4). Some researchers have argued that non-government standards could be considered 'relevant international standards' under this provision. ${ }^{80}$ However, in the recent US-Tuna II case, the Appellate Body restricted the definition of 'international standardizing organization' to one which is open to the standardizing bodies of all WTO Members. ${ }^{81}$ Standards adopted by the ISO, which comprises representatives of national standardization bodies, are more likely to be considered relevant international standards under this provision than would other non-governmental standards without such a broad international character. ${ }^{82}$

\section{CONCLUDING OBSERVATIONS ON THE LINKS BETWEEN VIRTUAL WATER, INTERNATIONAL TRADE LAW, AND WATER SCARCITY}

The international trade in virtual water is, as noted, related in significant part to global agricultural trade. The failure to put a price on water distorts trade in agricultural products and their derivatives and hurts our ability to address the growing issues of water scarcity. Liberalization of trade laws in the absence of water charges may not be good for conservation. If trade barriers are removed and even if subsidies are limited or eliminated, there will still be an incentive to use cheap water. This means that trade liberalization in the absence of putting a price on water could make the problems of water scarcity worse globally.

Domestic water pricing is one of the most called-for mechanisms for managing international trade in virtual water. ${ }^{83}$ The OECD recommends that countries ensure that charges for water supplied to agriculture reflect full supply costs, including opportunity costs and externalities, and cites evidence that raising water charges improves efficiency rather than reducing output. ${ }^{84}$ The WTO 2010 World Trade Report calls water pricing the best policy for managing the potential environmental impact of virtual water trade. ${ }^{85}$

Putting a price on water raises serious equity issues for poor rural farmers who survive on subsistence farming, which must be addressed. One possibility would be a lifeline exclusion for basic needs and certain uses and lower rates for other specific uses, as is done in some urban settings. Water rates can be differentiated to accommodate different equity concerns without sacrificing the beneficial effects of putting a price on water generally.

Water pricing also raises competitiveness concerns, such as those discussed in connection with carbon charges. If not all countries establish water -pricing schemes or different countries significantly under-price water, producers in countries in which

80 Bernstein and Hannah, above n 68.

81 In that case, the $\mathrm{AB}$ found that the AIDCP was not an international standardizing organization because it was not open to the relevant bodies of all Members. Appellate Body Report, US - Tuna II, above n 54, paras 398-99.

82 Kloeckner, above n 62.

83 For example, Garrido et al., above n 32; Le Vernoy and Messerlin, above n 17.

84 OECD, Sustainable Management of Water Resources in Agriculture (Paris: OECD, 2010).

85 World Trade Organization, above n 15. 
water has no price or is under-priced will have an advantage in water-intensive sectors such as agriculture. This could create a situation of water 'leakage', somewhat analogous to the concern about carbon leakage, where a shift in production to countries which do not price water counteracts water savings in countries which do price water. In the absence of a global consensus regarding pricing, concern that pricing would hurt domestic agricultural production could create powerful political obstacles to establishing water-pricing measures.

International coordination of national water-pricing systems might be considered. Some scholars have suggested a water-pricing agreement. ${ }^{86}$ Such an agreement could likely be developed to be consistent with WTO rules and principles, but it would be extremely difficult to negotiate and implement. A more workable alternative might be an international standard, or even international guidance, on water pricing, to which countries could voluntarily commit. Such a standard could be sponsored and hosted by a non-governmental organization, or by an international organization, and could incorporate pricing guidelines which countries agree to implement once they commit.

Already there is much attention to a projected global food production problem. Trade liberalization in agriculture, with accompanying trade in virtual water, could, as noted, make the water-scarcity problem worse. This, in turn, could give rise to greater problems in global food production to meet growing international demand for food. Thus, if we want to address the global food problem, we need to address the price issue in water, the subsidy issue connected to water, and the ways to reduce the demand for water, to use it more efficiently, and to inform consumers about the water used in production. We cannot afford to further trade law without considering the impacts for the projected water crisis in this century and addressing the link.

Powerful economic and political interests have impeded progress in liberalizing agricultural trade. These continue in the Doha Round. However, there is now a new dimension to consider: the impact of trade negotiations on the problems of water scarcity and on the trade in virtual water. This has implications for the methodologies used in international trade law. Specialists with knowledge of water resources and the virtual trade in water should appropriately be included in relevant international trade law discussions, and in particular in relevant Doha Round negotiations related to agriculture and to relevant water subsidies. Conversely, those concerned with water resources and food policy ought to reflect upon the implications of trade agreements for conserving such resources and for their equitable distribution.

While this article has focused on international trade law through the WTO, the methodological implications equally apply to regional and in some cases bilateral trade negotiations. 